\title{
Toward a Uniform Court Practice in the Republic of Macedonia $^{1}$
}

\author{
Jelena Ristik, PhD \\ Assistant Professor School of Law, \\ University American College Skopje Republic of Macedonia
}

Doi: 10.19044/esj.2017.v13n28p215 URL:http://dx.doi.org/10.19044/esj.2017.v13n28p215

\begin{abstract}
Despite the different perceptions regarding the status and treatment of the court practice in the Republic of Macedonia, judicial and state authorities are united in their view that there is a need for achieving a higher degree of uniformity of court practice. The need for a higher degree of uniformity of court practice was also noted by the European Union within its latest reports on the progress of the Republic of Macedonia as a candidate country for membership in the European Union as well as in the recent Report on Macedonia: Assessment and recommendations of the Senior Experts' Group on systemic Rule of Law issues 2017. This paper will try to resolve the various different interpretations as regards the court practice in Macedonia and define its role, treatment and application. This will be achieved mainly through analysis of the relevant national legislation. Further, possible new tools will be considered for achieving a greater uniformity of court practice. It will be argued that the court practice should serve as an additional means of argumentation within the reasoning of court judgments, which will contribute to increasing the degree of uniformity of court practice and rule of law as well. Finally, some suggestions will be given in order to provide for better conditions for the Supreme Court to exercise its constitutional competence to ensure the uniform application of the laws by the courts and thus ensure the existence of a uniform court practice.
\end{abstract}

Keywords: Uniformity, court practice, tool of argumentation, Supreme Court, Republic of Macedonia

\footnotetext{
${ }^{1}$ This paper is based on an analysis that was conducted by the author of the paper, within the Project "Supporting the Establishment of Unified Court Practice in the Macedonian Legal System", implemented by the Center for Legal Research and Analysis and funded by the British Embassy - Skopje, 2016
} 


\section{Introduction}

According to a research on the status and treatment of the court practice in the legal system of the Republic of Macedonia ("RM" or "Macedonia"), where the research methodology included interviews with key representatives of the judiciary and the public administration, various opinions and interpretations were presented on the role, the level of obligatoriness and the manner of usage of the court practice. However, despite the different perceptions regarding the status and treatment of the court practice, all members of the judicial and state authorities were united in their view that there is a need for achieving a higher degree of uniformity of the court practice (Center for Legal Research and Analysis, 2015).

One of the constitutional competences of the Supreme Court of the Republic of Macedonia ("Supreme Court") is ensuring uniform application of laws by the court (Constitution of the Republic of Macedonia, Article 101). However, some provisions in the procedural laws sometimes prevent the Supreme Court from exercising its constitutional competence to ensure the uniform application of the laws by the courts and thus ensure the existence of a uniform court practice.

The necessity of achieving a higher degree of uniformity of the court practice in Macedonia and the role of the Supreme Court in that regard is also noted in the recent Report on Macedonia: Assessment and recommendations of the Senior Experts' Group on systemic Rule of Law issues 2017, led by Reinhard Priebe and issued by the European Commission on 14 September 2017 ("Priebe Report 2017"). Namely, the Priebe Report 2017 notes that "the importance of the role of the Supreme Court should be emphasised in providing appropriate safeguards for clarity and foreseeability through greater uniformity of practice".

The need for a higher degree of uniformity of the court practice in RM was noted by the European Union ("EU") as well, within its latest reports on the progress of RM as a candidate country for EU membership (European Commission, 2014; European Commission 2015; European Commission 2016). The necessity for improved reasoning and transparency of court judgements was also noted in the EU reports (European Commission, 2016).

In order to provide a starting base for further research as regards reaching a higher level of uniformity of the court practice, it is first necessary to reach a single interpretation as regards the role, treatment and application of the court practice in RM. This paper will try to resolve the various different interpretations as regards the court practice in Macedonia and define its role, treatment and application. This will be achieved mainly through analysis of the relevant national legislation. Further, possible new tools will be considered for achieving a greater uniformity of court practice. 
It will be argued that the court practice should serve as an additional means of argumentation within the reasoning of court judgments, which will contribute to increasing the degree of uniformity of court practice and rule of law, in general. Finally, some suggestions will be given in order to provide for better conditions for the Supreme Court to exercise its constitutional competence to ensure the uniform application of the laws by the courts and thus ensure the existence of a uniform court practice.

\section{Court Practice in Anglo-Saxon and Continental Law}

In order to provide a solid starting point for resolving the dilemmas relating to the court practice in $\mathrm{RM}$, it is first necessary to distinguish between the meaning of the court practice in the Anglo-Saxon law and its meaning in the Continental law. In this regard, the differences between the meaning of the term "court practice" in the context of Anglo-Saxon law and the meaning of the term "court practice" in the context of Continental law will be explained.

The court practice can be defined as "a series of court judgments by which same general legal norm is applied in the same way" (Bajaldžiev, 2004, p.148). The adoption of a judgment means that a single legal act, which resolves a particular dispute, is adopted. Having in mind the latter, the judgment has an effect only in respect to the particular case. The court adopts the judgment on the basis of relevant general legal act, which represents a source of law. However, there are also cases when the court judgment, even though it represents a single legal act, is treated as a general legal act, and as such it is considered a source of law. In such cases, the effect of the court judgment is extended to all identical future cases (Bajaldžiev, 2004, p.146).

In this sense, depending on the importance and the value attributed to the court decisions, the court practice can be divided into court practice in the context of Anglo-Saxon law and court practice in the context of Continental law. Namely, for the purposes of this analysis, it is necessary to explain the difference between "the bindingness of court decisions in the countries of common law and the importance of unified court practice formation in the countries of civil law" (Ambrasienè \& Cirtautienè, 2009, p.61).

\section{Court Practice in Anglo-Saxon Law}

For the countries of common or Anglo-Saxon law the doctrine of stare decisis is characteristic, according to which the courts should adhere to past court decisions when deciding pending and future cases that contain substantially similar facts (Fon \& Parisi, 2006, p.520; Lindquist \& Cross, 2008, p.4). This means that the previous court decisions (court precedents) represent a source of law. Namely, in the Anglo-Saxon law, the court 
practice, also known as precedent law (case law), belongs among the sources of law and has the force of law. It should also be kept in mind that the judgments adopted by the highest courts represent a source of law (Bajaldžiev, 2004, p.146) and they are binding for the lower courts (Lindquist \& Cross, 2008, p.4).

The doctrine of stare decisis can be vertical and horizontal. Vertical stare decisis mean that the lower courts adhere to the decisions of the courts that have supervisory jurisdiction, i.e. the courts that have jurisdiction to abolish or change the decision of the lower courts. Horizontal stare decisis mean that a court follows and adheres to its own decisions (Mead, 2012, p.790). However, lower courts should modify some of its previous decisions, if they had been the subject of intervention by a higher court, in accordance with the decision of the higher court (Mead, 2012, p.797).

The court precedent can be divided in two elements: ratio decidendi and obiter dicta (Lücke, 1989, p.36).

Namely, the obligatory part of the previous court decision is in the element ratio decidendi (reason for the decision) (Lücke, 1989, p.38), which consists of "the material facts of the case plus the actual court decision" (Lücke, 1989, p.41). The element obiter dicta refers to opinions or analyzes that are expressed in the previous court decision, but are not essential to the actual decision and have no obligatory, but merely persuasive character (Harding \& Malkin, 2012, p.243-244). Only ratio decidendi is obligatory for the judges as regards future similar cases.

\section{Court Practice in Continental Law}

On the other hand, for the countries of civil or Continental law the doctrine of jurisprudence constante is characteristic, according to which judges should consider themselves bound to follow certain consolidated trend of court decisions (Fon \& Parisi, 2006, p.520). Namely, this doctrine emphasizes the need to set up a single court practice in the countries of Continental law. According to this doctrine, previous court decisions are not obligatory for the judges (Fon \& Parisi, 2006, p.522) and do not represent a formal source of law (Alegro, 2005, p.787).

However, within a typical jurisdiction of the civil law, even if the "precedents" are not obligatory, it can be argued that the decisions of the higher courts have influence on the decisions of the lower courts. Namely, the lower courts conduct their own analysis in connection to a certain case, while applying the existing laws, but their decisions could be abolished or altered by the higher courts, if it has been decided in a manner inconsistent with the previous decisions of the higher courts.

According to that, itt may be concluded that the decisions of the higher courts provide "authoritative argument" for the lower courts regarding 
the manner of interpretation of the law, although the lower courts are not formally obliged to follow that argument (Alegro, 2005, p.788-789).

\section{National Legal Framework Relevant for Court Practice}

The provisions of the national legislation, which are relevant in terms of the status, treatment and manner of application of the court practice in RM, are located in several legal acts. The Constitution of the Republic of Macedonia ("Constitution"), as the highest legal act, which, inter alia, defines the sources of law, represents the basis for the analysis of the aforementioned issues.

\section{Constitution and Law on Courts}

The basic starting point of any discussion on the status and treatment of the court practice within the legal system of RM is Article 98 of the Constitution (replaced by paragraph 1 of Amendment XXV). More specifically, it is the second paragraph of Article 98 of the Constitution, according to which "courts adjudicate based on the Constitution and the laws, and the international agreements ratified in accordance with the Constitution". This constitutional provision is almost literally replicated in the first paragraph of Article 2 of the Law on Courts, where it is stipulated that "the courts adjudicate and base their decisions on the Constitution, the laws and the international agreements ratified in accordance with the Constitution".

Article 98 of the Constitution and Article 2 of the Law on Courts explicitly foresee the formal sources of law in RM. Namely, having in mind the formulation of these articles, it could be noted that the court practice is not a formal source of law and that the courts cannot make decisions based on the court practice, or based on previous court decisions.

\section{Procedural Laws}

Having in mind the foregoing, it could be noted that Macedonia has the characteristics of a country that belongs to the Continental law, for which the doctrine of jurisprudence constante is characteristic and where previous court decisions are not binding for the judges. However, certain deviations from this rule, with elements of the doctrine of stare decisis, can be found in some procedural laws. In this sense, such provisions can be found in the Law on Civil Procedure.

\section{Law on Civil Procedure}

Article 386 of the Law on Civil Procedure, in the context of the provisions governing the revision, provides that "the court to which the case was returned for a retrial is bound to that case by the legal understanding on 
which the decision of the revision court is based, by which the challenged second instance judgment was abolished, or by which the second instance and the first instance judgment were abolished ".

Namely, this provision suggests a formal bindingness of the lower court to the decisions of the higher court (in this case the Supreme Court) in a retrial, where it can be concluded that it contains elements of the vertical stare decisis, used in the common law. At the same time, in the context of this provision, it should be noted that the term "legal understanding", which is used in Article 386 of the Law on Civil Procedure, represents a relatively wide and imprecise concept that requires further interpretation and refinement.

\section{Law on Administrative Disputes}

Similarly, Article 52 of the Law on Administrative Disputes provides that "when a court annuls an act against which an administrative dispute was initiated, the case returns in the state in which it was before the adoption of the annulled act", where "if according to the nature of the matter that was the subject of the dispute, another act should be adopted instead of the annulled one, the competent authority is obliged to act without delay...the competent authority shall be bound by the legal opinion of the court, as well as by the remarks of the court regarding the procedure".

However, the Law on Administrative Disputes does not contain provisions regarding a possible formal bindingness of the Administrative Court with the legal opinion expressed in certain decisions of the higher courts, as is the case with the Law on Civil Procedure.

\section{Law on Criminal Procedure}

Neither the Law on Criminal Procedure contains any provisions in this regard. It may be argued to some extent that Article 462 of the Law on Criminal Procedure, which is a part of the provisions governing the request for protection of legality, implicitly emphasizes and confirms the importance of the indications of the Supreme Court in the retrial. Namely, this article provides that in situation when "the final judgment is abolished and the case is sent back for retrial...before the first instance or the second instance court, the parties may present new facts and submit new evidence and propose procedural actions to clarify the issues identified by the Supreme Court in its decision...".

However, the Law on Criminal Procedure does not contain provisions that directly or indirectly refer to an eventual formal bindingness of the lower courts to the legal understanding expressed in the decision adopted by the higher courts, as in the case of Article 386 of the Law on Civil Procedure. 


\section{Court Practice as a Tool of Argumentation?}

The issue as regards the status of the court practice as a source of law is not the only issue that arises from the wording of Article 98 of the Constitution. There are other issues arising as well, whose answer requires further interpretation of this article, because there is no single opinion in connection to the answer to these questions.

Namely, it is clear that court practice is not a formal source of law. However, there is a diversity of opinions as to whether the court practice could and should serve as an additional means of argumentation within the rationale of a particular court decision, whereby the court, while interpreting the law, will use as a reference a court practice, i.e. will refer to a prior court decision (Center for Legal Research and Analysis, 2015). Of course, the ultimate goal would be to increase the uniformity of the court practice, and thus achieve a greater legal certainty as well as a greater degree of transparency of court proceedings.

When interpreting this provision, it should be kept in mind that the courts apply the Constitution, the laws and the international agreements, as formal sources of law in RM, through the adoption of court decisions. Also, it should be considered in the interpretation that the rule of law and the respect for the generally accepted norms of the international law are included among the basic principles of the constitutional order of RM (Constitution of the Republic of Macedonia, Article 8).

The principle of the rule of law represents "the dominant organizational model of the modern constitutional law and the international organizations (including the United Nations and the Council of Europe)" (European Commission, 2014a, p.3), whereby it contains a set of principles and standards arising from it. Among the principles and standards arising from the principle of the rule of law, the following are included: legality, which means transparent, accountable, democratic and pluralistic process of adoption of the laws; legal certainty; prohibition of arbitrariness by the executive authority; independent and impartial tribunal; effective judicial review, which includes the respect for fundamental rights; and equality before the law (European Commission, 2014a, p.4).

All these principles are not just formal or procedural requirements. In fact, they represent the basic means of ensuring respect for democracy and human rights, as well as compliance with them. For this reason, it can be asserted that the rule of law represents "constitutional principle which has formal and material components" (European Commission, 2014a, p.4).

Having in consideration that through the court decisions the law has actually been applied to a particular set of facts, it appears that using court practice as an additional means of argumentation will contribute to greater uniformity of court practice and thus provide greater respect for the principle 
of equality before the law, which stems from the principle of rule of law. At the same time, given that the principle of legal certainty generally refers to "non-retroactivity of the law, accessibility and predictability of the legal provisions and guarantee for a uniform interpretation of the laws" (Predescu \& Safta, c.2009, p.4), it appears that using court practice as an additional means of argumentation and greater uniformity of court practice provide greater respect for the principle of legal certainty as well, which is also one of the principles stemming from the rule of law.

Namely, it could be noted that uniform court practice provides respect for the principle of rule of law, as one of the fundamental values of the constitutional order of RM. At the same time, it reinforces the fulfillment of the objectives and functions of the judicial authorities, which, inter alia, includes also "ensuring uniformity, equality ... and ensuring legal certainty based on the rule of law" (Law on Courts, Article 3).

The respect for the generally accepted norms of international law, as previously mentioned, is also one of the fundamental values of the constitutional order of RM. So, it is generally accepted that Article 38 of the Statute of the International Court of Justice ("ICJ") determines the sources of the norms of international law (Boczek, 2005, p.26), whereby the court practice is not considered a source of law. However, the wording of Article 38 of the Statute of the ICJ clearly suggests that it can be used as a means of interpretation of law.

In this sense, even if the doctrine of stare decisis, characteristic for the common law, does not exist in international law, the previous judgments of the ICJ have been used as references by the Court itself in its judgments, as well as by the states in their disputes. Namely, one could argue that the court decisions have a role of additional source of law and that they are very important in terms of setting legal rules and their content (Omar, 2011, p.1011).

In the context of the previous, it is also important to mention the manner of usage of the court practice by the Court of Justice of the EU (CJEU) and the European Court of Human Rights (ECtHR). The court practice of the CJEU does not represent a primary source of law, but it is considered as an additional means of argumentation when the law is applied. Namely, the CJEU refers to previous decisions of the Court in its decisions, whereby the practice of the Court evolved into a primary means of argumentation before the Court. The situation is similar with the ECtHR. Namely, the ECtHR in its decisions often refers to its previous decisions, when interpreting and applying the provisions of the European Convention on Human Rights (Center for Legal Research and Analysis, 2015).

When interpreting the provisions of Article 98 of the Constitution, in order to determine whether the court practice could be used as an additional 
means of argumentation when interpreting the law, in a manner that the court, in the rationale of its decision, would use as a reference court practice, i.e. would refer to a previous court decision, it should also be taken in consideration whether the reliance on court practice when adopting court decisions is possible and justified, without mentioning explicitly the consulted court practice.

Namely, the use of court practice in adopting court decisions, without specifying it within the frame of the decision rationale, contains within itself a potential for violation of the principles of legal certainty and transparency, which are principles that are part of the essence of the rule of law. Moreover, this issue should be also addressed because the courts, in the decision making process, generally consult court practice as an additional tool for interpreting the law, but there is no practice of explicitly referring to the consulted court practice in the rationale of the adopted decision (Center for Legal Research and Analysis, 2015).

\section{Supreme Court}

The Supreme Court, as the highest court in Macedonia, is responsible for ensuring uniform application of laws by the courts (Constitution of the Republic of Macedonia, Article 101). Namely, the Supreme Court, at a general session, inter alia, "determines principal standings and principal legal opinions on issues of importance for ensuring consistency in the application of the laws by the courts, on its own initiative or on the initiative by the meetings of judges or court departments", and it can also "consider issues related to the operation of the courts, law enforcement and court practice" (Law on Courts, Article 37). This means that the Supreme Court ensures uniformity in the application of laws by the basic, appellate and specialized courts in RM (Škarić and Siljanovska-Davkova, 2007, p.729), which means that it has a key role in the process of ensuring a uniform court practice.

The principal standings and the principal legal opinions, which the Supreme Court considers and approves at the general meeting, are mandatory for all the councils of the Supreme Court (Law on Courts, Article 37). This legal provision provides that the principal standings and the principal legal opinions, through which the role of the Supreme Court for ensuring the uniform application of laws by the courts on the whole territory of RM is expressed (Škarić and Siljanovska-Davkova, 2007, p.732), are binding only for its councils. However, when interpreting this provision, one must not neglect its responsibility to ensure the uniform application of the laws on the whole territory of RM, by which it takes care for the uniformity of court practice, using the principal standings and the principal legal opinions as main tools. Also, it should be kept in mind that the Supreme 
Court is the highest court in Macedonia and final instance for supervising the judgments.

In this sense, although the principal standings and the principal legal opinions are not formally binding for the lower courts, i.e. have only horizontal obligatory effect, similarly to the horizontal stare decisis within the common law, it could be argued that they have, at least, strong persuasive effect in the decision making process by the lower courts, i.e. they represent a strong authoritative argument in the interpretation and application of law by the lower courts.

Similar interpretation could also be applied to the decisions adopted by the councils of the Supreme Court. Namely, the decisions adopted by the Supreme Court are not formally binding for the lower courts and have inter partes effect. However, given that the Supreme Court is the highest court in Macedonia and the final instance for supervising the court decisions, whereby it is responsible, inter alia, to ensure uniform application of the laws and thus provide for the unification of court practice, it could be claimed that its decisions represent highly authoritative means in the interpretation and application of law by the lower courts in similar cases. Of course, it should also be kept in mind that there should be a consolidated trend of decisions, according to the doctrine of jurisprudence constante, i.e. that there should be a certain level of consistency of court decisions (Fon \& Parisi, 2006, p.520).

The Supreme Court has at its disposal several other tools in order to ensure uniformity in the application of the laws and uniform court practice. Namely, in order to pursue and consolidate the court practice, the Supreme Court prepares a collection of court decisions with sentences and concise explanations (Court Rulebook, Article 72). For the same purpose, a department of court practice has been established within the Supreme Court, whereby the President of the Supreme Court may establish a task force for harmonizing and monitoring the court practice in RM (Court Rulebook, Article 73). At the same time, the Information Center of the Supreme Court maintains database of final and non-final court decisions with integral text without anonymizing the data of the parties and other participants in the proceedings, whereby the manner of determining the levels and access to the court decisions is regulated by an act of the President of the Supreme Court (Law on Case Flow Management in the Courts, Article 11).

In the context of the jurisdiction for ensuring uniformity in applying the laws and thus uniformity of court practice, a very important tool for the Supreme Court is the revision by exception, provided for in Article 372(4) of the Law on Civil Procedure. Namely, this provision reads as follows: "The revision by exception is permitted as well against a second instance judgment, against which a revision cannot be submitted according to 
paragraph (2) of this Article $^{2}$, in case the second instance court allowed for that in the adopted judgment. The second instance court may allow a revision by specifying the scope of the legal issue that would be raised before the Supreme Court, in case it considers that the decision in the dispute depends on the resolution of some substantive-legal or procedural-legal issue, which is essential for ensuring uniform application of the law and unification of court practice. Within the rationale for the judgment, the second instance court is required to specify for which legal issue it allowed the revision and to cite the decisions that indicate uneven application of the law, as well as to explain the reasons why it considers that this is important for ensuring uniform application of the law and unification of court practice".

Certain court decisions adopted by the lower courts do not meet the conditions that are required in order to be submitted for review before the Supreme Court ${ }^{3}$. Namely, the procedural laws contain limitation as to which court decisions reach the Supreme Court for review. In such cases, appellate courts are practically the highest courts in the hierarchy of the court system, instead of the Supreme Court, while the Supreme Court is unable to exercise its constitutional competence to ensure the uniform application of the laws by the courts and thus ensure the existence of a uniform court practice.

Considering the previous, the revision by exception foreseen in the Law on Civil Procedure is very important tool for the Supreme Court in terms of ensuring uniformity of court practice. However, provisions similar to the aforementioned Article 372(4) of the Law on Civil Procedure do not exist in the other procedural laws.

\section{Departments of Court Practice}

In order to monitor and process the court practice, separate departments for court practice are established within the courts, while the President of the court, within the annual work schedule of the court, appoints a department president or a judge responsible for court practice. The data used in the process of processing the court practice are derived from the

2 According to article 372(2), parties may file for a revision against the second instance judgment, if the value of the dispute to the challenged part of the judgment exceeds $1,000,000$ denars.

3 For example, parties may file for a revision against the second instance judgment, if the value of the dispute to the challenged part of the judgment exceeds 1,000,000 denars (Article 372 of the Law on Civil Procedure (consolidated text), Official Gazette of the Republic of Macedonia No.7/2011); also, the person sentenced to unconditional imprisonment or juvenile imprisonment of at least one year and his counsel may submit a request for extraordinary review of a final judgment due to violations of the law in cases stipulated in this Law (Article 463 of the Law on Criminal Procedure, Official Gazette of the Republic of Macedonia No.150/2010) 
automated computer system for court cases management (ACMIS). The courts have the obligation to publish in a bulletin the adopted significant final decisions, systematized in legal areas, at least once a year (Court Rulebook, Article 72).

The courts normally operate in specialized court department (Court Rulebook, Article 66). At the sessions of the specialized court departments, issues that are of interest to the work of all councils, i.e. judges within the department are addressed, especially regarding the application of laws in certain areas, unification of court practice and improvement of the working method. A session of a specialized court department is convened by the department presidents on their own initiative or at the request of the department judges or the president of the court, when it is determined that there is an inconsistency between different department councils, particularly in the application of the law (Court Rulebook, Article 91).

The department of court practice coordinates the work of all departments in the court in performing the tasks pertaining to the recording and study of court practice (Court Rulebook, Article 74). Furthermore, the presidents of all the departments in the court are obliged to submit legal opinions and findings to the President of the department of court practice or the judge responsible for the court practice.

The President of the department of court practice determines the manner in which the department of court practice records the legal opinions adopted at a session of the department, at joint sessions of departments or sessions of judges, as well as the method of recording and publication of the court practice. Also, the President of the department of court practice is in constant communication with the presidents of the departments of court practice in the other courts (Court Rulebook, Article 75).

The establishment of the departments of court practice in the courts is essential in achieving a higher degree of unification of the court practice. Namely, the work of the Department of Court Practice within the Supreme Court is extremely important factor in fulfilling the task of the Supreme Court to ensure a uniform application of laws and unification of the court practice in the whole country.

Also, no less important is the work of the departments of court practice within the basic, appellate and administrative courts, which take care for processing, recording and publication of the court practice within the particular court, and thus greatly contribute to the elimination of any inconsistencies in the application of the law between the individual councils and in the unification of the court practice.

In this regard, the communication and coordination between the departments of court practice of the courts is also very important, especially between the courts of the same level of competence, in order to locate 
eventual inconsistencies in the application of law at the horizontal level between different courts. This manner of communication and coordination is especially important for the appellate courts, as courts of second instance jurisdiction. Namely, this manner of unification of the court practice is also very important because, as noted before, certain court decisions adopted by the lower courts do not meet the conditions that are required in order to be submitted for review before the Supreme Court.

\section{Conclusion}

Taking into consideration Article 98 of the Constitution and Article 2 of the Law on Courts, which explicitly foresee the formal sources of law in the Republic of Macedonia, it could be concluded that the court practice is not a formal source of law and that the courts cannot make decisions based on the court practice, i.e. based on previous court decisions.

Republic of Macedonia has the characteristics of a country that belongs to the Continental law, for which the doctrine of jurisprudence constante is characteristic and where previous court decisions are not binding for the judges. However, certain deviations from this rule can be found in some procedural laws, which contain elements of the doctrine of stare decisis. Such provisions can be found in the Law on Civil Procedure.

Based on the analysis of the procedural laws, it could be concluded that there is a degree of inconsistency between these laws. It creates confusion and opens additional dilemmas and space for different interpretations as to the level of obligatoriness of the decisions taken by the higher courts, the in decision making and application of law by the lower courts. Moreover, all of this can lead to a completely inappropriate conclusion that the level of obligatoriness of the decisions of the higher courts in the application of laws and the decision making by the lower courts is different for different legal areas. In any case, there is a need for harmonization of the procedural laws in this regard.

However, it should be noted as well that in these provisions one can at the same time see a tendency for emphasis of the importance of the decisions of the Supreme Court, as the highest court in the judicial hierarchy, in the application of the law by the lower courts, by which its responsibility for ensuring the uniform application of laws is expressed.

It could also be concluded that court practice should serve as an additional means of argumentation within the rationale of a particular court decision, whereby the court, while interpreting the law, will use as a reference a court practice, i.e. will refer to a prior court decision. Namely, the courts apply the Constitution, the laws and the international agreements, as formal sources of law in the Republic of Macedonia, through the adoption of court decisions. In this sense, using court practice as an additional means of 
argumentation when law is applied will contribute to greater uniformity of court practice and thus to greater legal certainty as well as greater transparency of court proceeding. Namely, uniform court practice provides respect for the legal certainty, as one of the principles stemming from the rule of law principle.

Certain court decisions adopted by the lower courts do not meet the conditions that are required in order to be submitted for review before the Supreme Court. In such cases, the Supreme Court is unable to exercise its constitutional competence to ensure the uniform application of the laws by the courts and ensure the existence of a uniform court practice. Moreover, in such cases the appellate courts are practically the highest courts in the hierarchy of the court system, instead of the Supreme Court.

However, the Law on Civil Procedure, unlike the other procedural laws, provides a mechanism for such cases to reach the Supreme Court, if the dispute depends on the resolution of some legal issue, which is essential for ensuring uniform application of the law and unification of court practice. In this sense, one possible solution, in order to enable the Supreme Court to fully exercise its competence to ensure the uniform application of the laws by the courts and thus ensure the existence of a uniform court practice, could be foreseeing similar mechanisms in the other procedural laws as well.

\section{References:}

1. Alegro, M.G. (2005). The Sources of Law and the Value of Precedent: A Comparative and Empirical Study of a Civil Law State in a Common Law Nation. Louisiana Law Review, Vol.65, No.2

2. Ambrasienè, D. \& Cirtautienè, S. (2009). The Role of Judicial Precedent in the Court Practice of Lithuania. Jurisprudencija, Vol.2

3. Assembly of the Republic of Macedonia. (2005). Amendments XX, XI, XXII, XXIII, XXIV, XXV, XXVI, XXVII, XXVIII, XXIX and XXX. Official Gazette of the Republic of Macedonia, No.107/2005

4. Assembly of the Republic of Macedonia. (1991). Constitution of the Republic of Macedonia. Official Gazette of the Republic of Macedonia, No.52/1991

5. Assembly of the Republic of Macedonia. (2013). Court Rulebook. Official Gazette of the Republic of Macedonia, No.66/2013

6. Assembly of the Republic of Macedonia. (2006). Law on Administrative Disputes. Official Gazette of the Republic of Macedonia, No.62/2006

7. Assembly of the Republic of Macedonia. (2011). Law on Civil Procedure (consolidated text). Official Gazette of the Republic of Macedonia, No.7/2011 
8. Assembly of the Republic of Macedonia. (2006). Law on Courts. Official Gazette of the Republic of Macedonia, No.58/2006

9. Assembly of the Republic of Macedonia. (2010). Law on Criminal Procedure. Official Gazette of the Republic of Macedonia, No. $150 / 2010$

10. Bajaldžiev, D. (2004). Introduction to Law, Kumanovo: Makedonska riznica

11. Boczek, B.A. (2005). International Law: A Dictionary, Dictionaries of International Law No.2, Lanham, Maryland/Toronto/Oxford: The Scarecrow Press Inc,

12. Center for Legal Research and Analysis. (2015). Unifying the Court Practice in Macedonia: Possibilities vs. Challenges, Skopje: Center for Legal Research and Analysis

13. European Commission. (2014a). Communication from the Commission to the European Parliament and the Council: A new EU Framework to Strengthen the Rule of Law, Brussels: European Commission

14. European Commission. (2017). Report on Macedonia: Assessment and recommendations of the Senior Experts' Group on systemic Rule of Law issues, Brussels: European Commission

15. European Commission. (2014). The Former Yugoslav Republic of Macedonia Progress Report 2014, Brussels: European Commissions

16. European Commission. (2015). The Former Yugoslav Republic of Macedonia Progress Report 2014, Brussels: European Commissions

17. European Commission. (2016). The Former Yugoslav Republic of Macedonia Progress Report 2014, Brussels: European Commissions

18. Fon, V. \& Parisi, F. (2006). Judicial Precedents in Civil Law Systems: A Dynamic Analysis. International Review of Law and Economics, Vol.26

19. Harding, M. \& Malkin, I. (2012). The High Court of Australia's Obiter Dicta and Decision-Making in Lower Courts. Sydney Law Review, Vol.34:239

20. Lindquist, S.A. \& Cross, F.C. (c2008). Stability, Predictability and the Rule of Law: Stare Decisis as Reciprocity Norm, Texas: University of Texas School of Law

21. Lücke, H.K. (1989). Ratio Decidendi: Adjudicative Rational and Source of Law. Bond Law Review, Vol.1, Issue 1

22. Mead, J.W. (2012). Stare Decisis in the Inferior Courts of the United States. Nevada Law Journal, Vol.12:728

23. Omar, S. (2011). Sources of International Law in the Light of Article 38 of the International Court of Justice, International Islamic 
University-Dawah Academy. Retreived from SSRN: http://papers.ssrn.com/sol3/papers.cfm?abstract_id=1877123

24. Predescu, I. \& Safta, M. (c.2009). The Principle of Legal Certainty, Basis for the Rule of Law Landmark Case-Law, Constitutional Court of Romania

25. Škarić, S. \& Siljanovska-Davkova, G. (2007). Consitutional Law, Skopje: Kultura 